\title{
SELECTION AND CHARACTERIZATION OF LOW $\beta$-GLUCAN MUTANTS FROM BARLEY
}

\author{
by \\ STEN AASTRUP \\ Carlsberg Research Laboratory \\ Department of Biotechnology \\ Gamle Carlsberg Vej 10, DK-2500 Copenhagen, Valby \\ Present address: Department of Brewing Chemistry
}

Keywords: Small scale malting, endo- $\beta$-glucanase, endosperm structure, cell wall thickness, mealy, steely, high lysine.

Four barley lines have been selected from $40,000 \mathrm{M}_{2}$ plants derived from sodium azide-treated seeds of the high $\beta$-glucan cultivar Minerva, on the basis of low viscosity of acid extracts of flour. Two lines show a minor decrease in total $\beta$-glucan content, and two lines are low in total $\beta$-glucan, exhibit rapid endosperm modification and display a mealy endosperm. The thickness of the endosperm cell walls in the low $\beta$-glucan mutants is 3.0-3.5 $\mu \mathrm{m}$ compared with $6.5 \mu \mathrm{m}$ for the parent variety Minerva. One of the low $\beta$-glucan mutants, has increased $\beta$-glucanase activity which might partly explain the increased rate of its modification during malting. The other mutant, M-737, has approximately the same amount of $\beta$-glucanase as Minerva and appears to be a genuine low $\beta$-glucan mutant. Malting studies confirmed the important role of endosperm cell walls as a barrier for enzyme dissemination.

\section{INTRODUCTION}

The major cell wall component of barley endosperm, mixed-linkage $(1 \rightarrow 3),(1 \rightarrow 4)-\beta-D$ glucan( $\beta$-glucan) has attracted attention since the basic studies of PreECE and MacKenzie (26), primarily because the polysaccharide has been implicated in certain filtration and haze prob- lems encountered in the brewing industry (8) and in decreased growth rates in poultry $(10,16)$. Furthermore, as a structural component of endosperm cell walls, $\beta$-glucan constitutes a physical barrier to the dissemination of hydrolytic enzymes from the scutellum and/or aleurone into the endosperm $(12,20,21,22,25)$ during malting. 
A low $\beta$-glucan mutant induced in a high $\beta$ glucan parent barley would be useful in studies of $\beta$-glucan synthesis (11) and as a source of genetic variation for barley breeding.

The present communication describes the induction and characterization of such mutants.

\section{MATERIALS AND METHODS}

\subsection{Selection of mutants}

The high $\beta$-glucan barley variety Minerva was treated with the mutagen $\mathrm{NaN}_{3}(19)$ and the $\mathrm{M}_{2}$ plants $\left(\mathrm{M}_{3}\right.$ seeds) were used as the basic material for subsequent selections. Single $\mathbf{M}_{2}$ plants $(40,000)$ were individually harvested and threshed. Half of the seeds from each plant were ground and acid extracts of the flour prepared (see 2.2). In the initial screening the viscosity of extracts was judged visually by inverting the tubes. Only the lowest viscosity extracts were kept for quantitative determinations using a viscometer. The 400 lines selected in this way were propagated in the green-house. The seeds of $\mathbf{M}_{3}$ plants were tested using a viscometer and 40 selected lines were sent to New Zealand (D.S.I.R., Research Farm, Lincoln) for further propagation. A final viscosity analysis of seeds of $\mathrm{M}_{4}$ plants led to the selection of four lines for detailed investigations. The $\mathrm{M}_{5}$ plants from these four lines and the high lysine mutant Risø 1508 (18) were obtained from the Carlsberg Research Farm, Hyldagergárd, Denmark.

\subsection{Viscosity determination}

Extraction of flour with $\mathrm{HCl}$ solution ( $\mathrm{pH} \mathrm{1.5)}$ and the determination of extract viscosity were carried out as previously described (2) except that the ratio of flour to acid solution was increased from $0.2 \mathrm{~g}$ flour $/ 2 \mathrm{ml}$ to $0.3 \mathrm{~g}$ flour $/ 2 \mathrm{ml}$.

\subsection{Chemical and enzymatic analyses}

Moisture content was determined by weighing seed samples ground in a Braun mill (Braun AG, Frankfurt/M, West Germany) before and after 2 hours at $130^{\circ} \mathrm{C}$, and 1 hour in a desiccator. Crude fiber was determined according to WENDE (1) using semi-automatic equipment (Fibertec, Tecator, Höganäs, Sweden). Flour samples for fat content measurements were dried and weighed before and after extraction with petroleum ether (b.p. $40-60^{\circ} \mathrm{C}$ ) in a Rafatec extraction unit (Teca- tor). Protein content was measured by the KJELDAHL method using the Tecator System with a selenium catalyst (Kjeltabs, Bie \& Berntsen, Copenhagen, Denmark). Starch was measured enzymatically according to THEANDER and ȦMAN (31) with the following modification: After washing three times in $80 \%(\mathrm{v} / \mathrm{v})$ ethanol the flour was autoclaved for 1 hour, and treated with Termamyl (Novo Industri A/S, Copenhagen, Denmark) and amyloglucosidase (Merck, Darmstadt, West Germany). The qualitative precipitation test for hordein was carried out as described by RHODES (27) on samples of ten grains. For amino acid analysis samples of flour $(50 \mathrm{mg})$ were hydrolysed in $5 \mathrm{ml} 6 \mathrm{M}-\mathrm{HCl}$, containing $0.05 \%(\mathrm{w} / \mathrm{v})$ phenol and $0.001 \mathrm{M}$-norleucine, for 24 hours at $110^{\circ} \mathrm{C}$ in evacuated ampoules. The samples were analysed on a Durrum D-500 amino acid analyser. Arginine, cysteine, methionine and tryptophane were not determined. Values for the amino acid composition were determined in duplicate and expressed as $\mathrm{g}$ amino acids per $100 \mathrm{~g}$ protein (Kjeldahl $\mathrm{N} \times 6.25$ ). Total $\beta$-glucan content was measured using the method of ANDERSON et al. (7).

Endo- $\beta$-glucanase activity was followed during malting. For each sample seeds (40) were ground in a mortar with sand, and extracted with $0.1 \mathrm{M}-\mathrm{NaCl}$ for 1.5 hours at room temperature, and activity measured using a small scale version of the viscosity method proposed by SANDEGREN and ENEBO (28). Barley $\beta$-glucan prepared according to the method of PREECE and MACKENZIE (26) was used as substrate. Viscosity was measured in a Contraves Low Shear 100 viscometer (Contraves AG, Zürich, Switzerland), with a sample volume of $400 \mu$ l. Activity was calculated from the increase in reciprocal specific viscosity, $\Delta\left(\eta_{\mathrm{sp}}{ }^{-1}\right)$, as $1000 \times \Delta\left(\eta_{\mathrm{sp}}{ }^{-1}\right) \times \min ^{-1} \times \mathrm{g}^{-1}$.

The standard deviation for all analyses was $<5 \%$ except for the starch analysis where it was $<4 \%$.

\subsection{Malting procedures}

Seeds were sieved according to malt house specifications (6) and only those larger than 2.5 $\mathrm{mm}$ in diameter were used in the experiments. For micro-malting $70 \mathrm{~g}$ was used and for decromalting 5 to $10 \mathrm{~g}$, the latter being approximately $1 / 10$ of a micro-malting (de(ci mi)cro-malting). 
During malting water uptake was determined by weighing the seeds. In the steeping period this was done after draining. Steeping was performed in cloth bags and consisted of three alternating periods of 8 hours in water and 16 hours in humid air (relative humidity 100\%). The seeds were transferred to plastic cups and allowed to germinate in humid air at $15^{\circ} \mathrm{C}$. Seeds were aerated and separated once a day during germination.

In the case of micro-malting grains were kilned in a laboratory oven for 16 hours at $50^{\circ} \mathrm{C}$ followed by 5 hours at 50 to $80^{\circ} \mathrm{C}$. Green malt samples of 50 grains were taken every day from the second day of malting, frozen in liquid nitrogen and stored at $-20{ }^{\circ} \mathrm{C}$ for subsequent malt modification analysis.

The decro-malting was carried out in the same manner with adjustments for the smaller number of seeds. The system consisted of a number of perforated plastic cups $(6 \mathrm{~cm}$ in height and 3.5 $\mathrm{cm}$ in diameter) standing on the perforated plate of a desiccator. During steeping the seeds were kept in small cloth bags $(7.5 \times 10 \mathrm{~cm})$ placed in the plastic cups. Germination was allowed to proceed in the cups and the humidity of the air was maintained by covering the bottom of the desiccator with water. The advantages of using decro-malting instead of germinating on sand or filter paper are that i) water uptake is easily followed and ii) the development of roots and acrospires is slower and the procedure is therefore more comparable to larger scale malting conditions. Samples of 80 seeds were taken at day 1 to 5 and at day 7 of the decro-malting, frozen in liquid nitrogen and stored in the freezer for malt modification (40 seeds) and enzyme (40 seeds) analysis.

\subsection{Analysis of endosperm modification}

The progressive modification of the endosperm during malting was followed by the Calcofluor method using an Image Analyser for quantification (4).

\subsection{Standard malt analyses}

These were carried out at the Carlsberg Central Laboratory according to described procedures (6).

\subsection{Evaluation of cell wall thickness and cell number}

Seeds were fixed in lysine periodate - paraformaldehyde (13). Following freezing in liquid nitrogen, $7 \mu \mathrm{m}$ sections were cut on a Reichert Jung Frigocut 2700 Cryotome (Jung, West Germany). To examine the cell walls, sections were transferred to moist gelatine-coated slides and stained with the fluorochrome Calcofluor and the protein-stain Fast Green (4). The sections were covered with a drop of water to prevent drying. The preparations were viewed under UVlight on a Reichert Univar microscope (Reichert, Austria) at $400 \times$ magnification. Photographs were taken on Kodak Ektachrome 400 film (Eastman Kodak, Rochester, New York, U.S.A.) using a Reichert Trimatic automatic camera. The thickness of the endosperm cell walls and the cell number were measured in the central region of dorsi-ventral longitudinal lateral sections from $1 / 8$ to $3 / 8$ through the seed. OLSEN and KREKLING (23) have found that material from this region is the most constant with respect to cell size and cell shape. The measurements were done on projections of the photographs on a white screen at a total magnification of $2,500 \mathrm{x}$. These were compared with the standard etched scale on each slide. The cell wall thickness of a seed is the average of 20 cell wall measurements and the cell wall thickness of a genotype is the average of 20 seed measurements. The cell number was judged by counting the number of cells falling wholly or in part within an area of 10,000 $\mu \mathrm{m}^{2}$ (comparable to $360 \mathrm{~cm}^{2}$ on the projection screen). The reported values are based on the average of two sets of 20 seeds. Standard errors for each value are given.

\section{RESULTS}

\subsection{Chemical and morphological properties}

The analyses were carried out mainly on the $\mathbf{M}_{5}$ seeds harvested in New Zealand, except for the amino acid analyses which were done on the $\mathrm{M}_{6}$ seeds, Danish-grown materials. For comparison, viscosity and total $\beta$-glucan content were also determined on the $M_{6}$ seeds. It is seen that differences in both viscosity and total $\beta$-glucan content are more distinct in the New Zealand material than in Danish-grown material (Table I). This may be due to the warmer and drier 
Table I.

Chemical properties of Minerva and the four selected lines.

\begin{tabular}{|c|c|c|c|c|c|c|c|c|c|c|}
\hline \multirow[b]{2}{*}{ Generation } & \multicolumn{2}{|c|}{$\begin{array}{l}\text { Acid } \\
\text { extract } \\
\text { viscosity } \\
\left(\mathrm{cP}, 20^{\circ} \mathrm{C}\right)\end{array}$} & \multicolumn{2}{|c|}{$\begin{array}{c}\text { Total } \\
\beta \text {-glucan } \\
(\% \text { d.m. })\end{array}$} & \multirow{2}{*}{$\begin{array}{c}1000 \\
\text { grain } \\
\text { weight } \\
\text { (g) }\end{array}$} & \multirow{2}{*}{$\begin{array}{c}\begin{array}{c}\text { Crude } \\
\text { fiber }\end{array} \\
\text { (\% d.m.) } \\
M_{4}\end{array}$} & \multirow{2}{*}{$\begin{array}{c}\text { Fat } \\
\frac{(\% \text { d.m. })}{M_{4}}\end{array}$} & \multirow{2}{*}{$\begin{array}{c}\text { Starch } \\
\text { (\% d.m.) } \\
M_{4}\end{array}$} & \multirow{2}{*}{$\begin{array}{c}\text { Protein } \\
\text { (\% d.m.) } \\
\mathrm{M}_{4} \\
\end{array}$} & \multirow{2}{*}{$\begin{array}{c}\text { Hordeins } \\
\mathrm{M}_{4}\end{array}$} \\
\hline & $\mathbf{M}_{4}$ & $\mathbf{M}_{5}$ & $\mathbf{M}_{4}$ & $\mathbf{M}_{5}$ & & & & & & \\
\hline Minerva & 1030 & 180 & 5.9 & 4.9 & 49.7 & 3.9 & 2.3 & 51.5 & 17.5 & + \\
\hline M-737 & 2.1 & 1.9 & 2.7 & 2.5 & 37.0 & 4.6 & 2.6 & 53.0 & 18.5 & + \\
\hline M-1460 & 2.0 & 1.7 & 2.3 & 2.0 & 37.6 & 6.2 & 3.2 & 48.0 & 17.5 & - \\
\hline M-699 & 2.1 & 2.0 & 4.7 & 4.6 & 44.3 & 4.6 & 2.3 & 53.6 & 18.2 & + \\
\hline M.892 & 5.0 & 2.4 & 4.6 & 4.5 & 46.1 & 4.8 & 2.4 & 49.5 & 18.4 & + \\
\hline \multicolumn{11}{|c|}{$\begin{array}{l}\text { cP: } \text { centi-poise } \\
\text { d.m.: dry matter } \\
\text { M }_{4}: \text { Material grown in New Zealand 1980/81 } \\
\mathbf{M}_{5}: \text { Material grown in Denmark } 1981\end{array}$} \\
\hline
\end{tabular}

Table II.

Protein content and amino acid composition of seeds from Minerva, M-737, M-1460 and Risø 1508 grown in Denmark.

\begin{tabular}{|c|c|c|c|c|}
\hline & Minerva & M-737 & M-1460 & $\begin{array}{l}\text { Risø } \\
1508\end{array}$ \\
\hline Protein (\% d.m.) & 11.5 & 11.7 & 11.0 & 11.1 \\
\hline \multicolumn{5}{|c|}{ Amino Acid $(\mathrm{g} / 16 \mathrm{~g} \mathrm{~N})$} \\
\hline ASP & 5.4 & 6.0 & $8.3^{+}$ & $8.9^{+}$ \\
\hline THR & 3.0 & 3.0 & 3.5 & 3.4 \\
\hline SER & 2.8 & 2.9 & 3.4 & 2.7 \\
\hline GLU & 24.0 & 24.9 & $16.5^{+}$ & $16.5^{+}$ \\
\hline PRO & 11.0 & 11.0 & $6.9+$ & $7.7^{+}$ \\
\hline GLY & 4.0 & 4.2 & $5.8+$ & $5.9+$ \\
\hline CYS & n.d. & n.d. & n.d. & n.d. \\
\hline ALA & 4.0 & 4.2 & $5.3^{+}$ & $5.5^{+}$ \\
\hline VAL & 5.5 & 5.6 & 5.5 & 6.2 \\
\hline MET & n.d. & n.d. & n.d. & n.d. \\
\hline ILE & 3.9 & 4.2 & 3.7 & 3.9 \\
\hline LEU & 7.0 & 7.4 & 7.1 & 7.2 \\
\hline TYR & 2.5 & 2.4 & 3.0 & 2.8 \\
\hline PHE & 4.3 & 4.7 & $3.7^{+}$ & $3.4^{+}$ \\
\hline HIS & 2.1 & 2.2 & 2.7 & 2.5 \\
\hline LYS & 3.3 & 3.9 & $5.3^{+}$ & $5.3^{+}$ \\
\hline ARG & n.d. & n.d. & n.d. & n.d. \\
\hline TRP & n.d. & n.d. & n.d. & n.d. \\
\hline
\end{tabular}

ripening period in New Zealand resulting in an increased viscosity of acid extracts (17) and higher levels of total $\beta$-glucan content.

Very low viscosities of the acid extracts are seen for all the selected lines, which implies that they have very little acid soluble $\beta$-glucan $(2,29)$. The low viscosities are paralleled by large decreases in total $\beta$-glucan content for the mutants M-737 and M-1460 compared with Minerva, while M699 and M-892 show a smaller decrease. The grain weights of M-737 and M-1460 are significantly decreased compared to Minerva, and accompanied by higher fiber and fat contents, especially in M-1460. No significant differences in the starch or protein contents were found (Table I), although the material harvested in New Zealand (Table I) was higher in protein than the Danish-grown material (Table II).

Mutant M-1460 can be distinguished from the other four genotypes in that it lacks hordeins (Table I). Since M-1460 also has enlarged embryos and shriveled endosperms, it is possible that M-1460 might be a high lysine mutant of the Risø-1508 type (18). This possibility was examined by comparing the amino acid composition of total seed protein from Minerva, M-737, M1460 and Risø 1508 (Table II). As expected M- 
Table III.

Analyses of micro-malt derived from Minerva and the four selected lines grown in Denmark.

\begin{tabular}{lccccc}
\hline & Minerva & M-737 & M-1460 & M-699 & M-892 \\
\hline Moisture content, \% & 5.8 & 5.0 & 5.1 & 5.9 & 5.7 \\
Extract content, fine grind, ${ }^{\circ}$ Plato & 72.9 & 75.6 & 69.6 & 73.5 & 62.1 \\
Wort colour, EBC units & 4.1 & 8.8 & 7.5 & 4.4 & 3.8 \\
Viscosity of wort, cP at $20^{\circ} \mathrm{C}$ & 1.62 & 1.45 & 1.46 & 1.60 & 1.67 \\
Modification, \% & 75.3 & 92.5 & 98.5 & 72.8 & 69.4 \\
\hline
\end{tabular}

737 displays similar amino acid composition to that of Minerva. In contrast, the amino acid composition of M-1460 differs significantly from Minerva and M-737 but is similar to that of the Risø-1508 mutant.

\subsubsection{Endosperm vitreousness}

Transverse sections of Minerva and the four selected lines revealed that the endosperm of Minerva was highly steely (vitreous), M-699 and M-892 moderately steely, M-1460 was almost entirely mealy while M-737 was completely mealy. The contrasting appearance of the endosperm of Minerva and of the mutant M-737 is illustrated in Figure 1. Mealyness has normally been associated with good malting quality, that is, good malting barleys have a high percentage of mealy grains (24).

\subsection{Germination behaviour}

When seeds of Minerva and the four selected lines from the New Zealand harvest were germinated in the decro-malting system, M-1460 took up moisture most readily, reaching a level of about $47 \%$ within 3 days, while Minerva and the three other lines reached a level of about $42 \%$ in the same period (Figure 2). The roots and acrospires appeared first in M-1460 followed by M737 and finally M-699, M-892 and Minerva. After seven days, the endosperm of M-1460 was significantly more modified than that of Minerva, M-699 and M-892 (77 vs 40\%) (Figure 3). The modification of mutant M-737 was intermediate, and the curve showed a sigmoidal appearance. The same kind of difference in curvature observed here between Minerva and M-737 was also observed in another study in which the good malting variety Nordal was compared with Minerva (5).

To determine if the higher modification rates observed for M-1460 and M-737 were due to higher endo- $\beta$-glucanase activities, assays for this enzyme were carried out during decro-malting (Figure 4). M-1460 has a markedly higher endo- $\beta$-glucanase activity than either Minerva or M-737 which display similar levels of this enzyme. Thus the very high modification rate of M-1460 may be due, in part at least, to its high

Table IV.

Endosperm cell wall thickness and cell number measured on Calcofluor/Fast Green stained thin sections from Minerva and the four selected lines grown in New Zealand.

\begin{tabular}{|c|c|c|}
\hline & $\begin{array}{l}\text { Cell wall thickness } \\
\qquad(\mu \mathrm{m})\end{array}$ & Cell number $x\left(10^{4} \cdot \mu \mathrm{m}^{2}\right)^{-1}$ \\
\hline Minerva & $6.5 \pm 0.5 \mathrm{a}$ & $7.7 \pm 0.6 \mathrm{c}$ \\
\hline M-737 & $3.0 \pm 0.4 b$ & $8.3 \pm 1.2 \mathrm{c}$ \\
\hline M-1460 & $3.6 \pm 0.4 b$ & $7.3 \pm 1.9 \mathrm{c}$ \\
\hline M-699 & $6.2 \pm 0.6^{a}$ & $8.2 \pm 1.1 \mathrm{c}$ \\
\hline M-892 & $6.0 \pm 0.7 \mathrm{a}$ & $8.0 \pm 0.8 c$ \\
\hline \multicolumn{3}{|c|}{$\mathrm{a} \hookleftarrow \mathrm{b}: * * *$} \\
\hline \multicolumn{3}{|l|}{$\mathrm{a} \multimap \mathrm{a}: \mathrm{n} . \mathrm{s}$} \\
\hline \multicolumn{3}{|l|}{$\mathrm{b} \mapsto \mathrm{b}:$ n.s. } \\
\hline c $\multimap$ c: n.s. & & \\
\hline
\end{tabular}




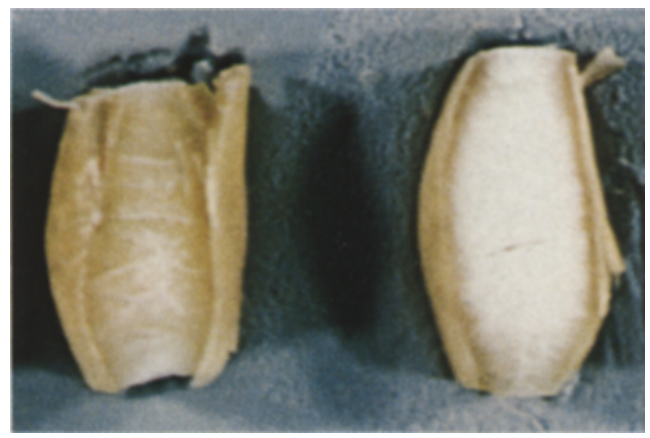

a

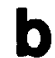

Figure 1: Half grain of (a) Minerva with mealy endosperm and (b) M-737 with steely endosperm.

endo- $\beta$-glucanase activity. On the other hand, the increased modification rate of M-737 can not be explained in this manner.

A micro-malting of Minerva and the four selected lines derived from the $\mathbf{M}_{6}$-seeds, Danishgrown material showed the same ranking of the genotypes. The rate of modification, however, was faster compared to the decro-malting. Cal-

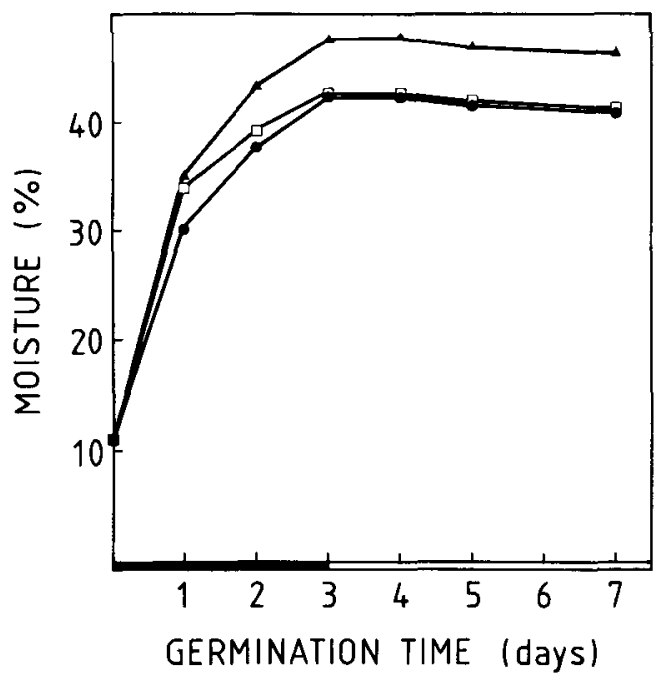

Figure 2: The relationship between germination time and moisture content for decro-malted ( $\square$ ) Minerva, M-699 and M-892 (no significant difference between these genotypes), (O) M-737 and (A) M-1460. steeping time.

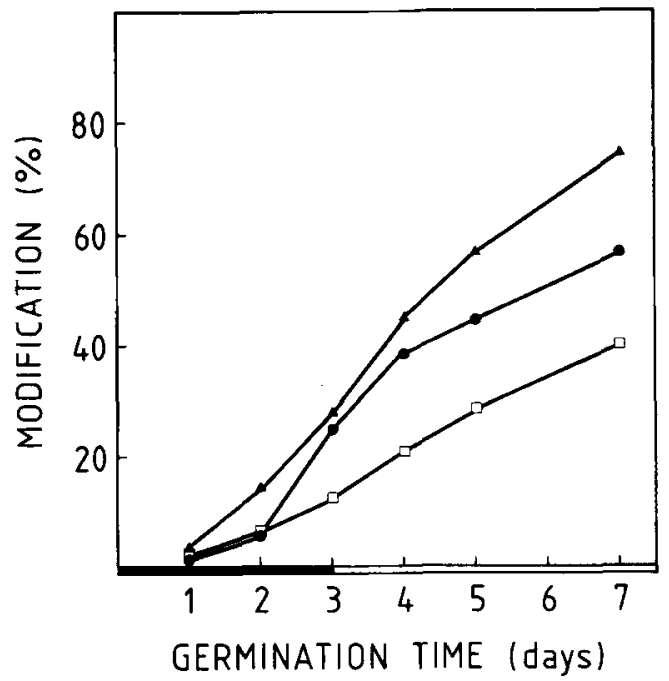

Figure 3: The relationship between germination time and modification for decro-malted ( $\square$ ) Minerva, M699 and M-892 (no significant difference between these genotypes), (O) M-737 and (A) M-1460. steeping time.

cofluor analyses gave modification values after five days of $63 \%, 59 \%, 65 \%, 87 \%$ and $97 \%$ for Minerva, M-699, M-892, M-737 and M-1460, respectively. After kilning, the values were increased to $75 \%, 69 \%, 73 \%, 92 \%$ and $99 \%$, respectively. The standard analyses of the malts are shown in Table III. The malts of M-737 and M-

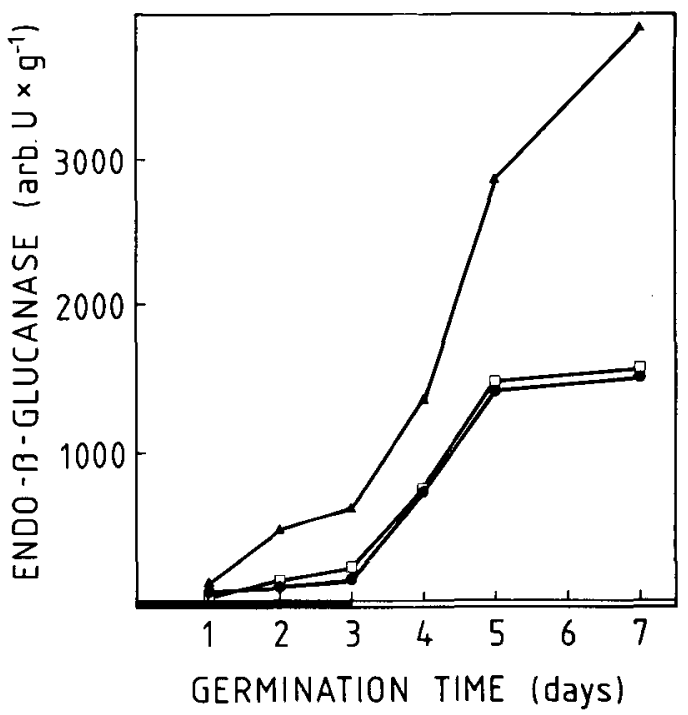

Figure 4: The relationship between germination time and enzyme activity for decro-malted $(\square)$ Minerva, (O) M-737 and (A) M-1460. steeping time. 

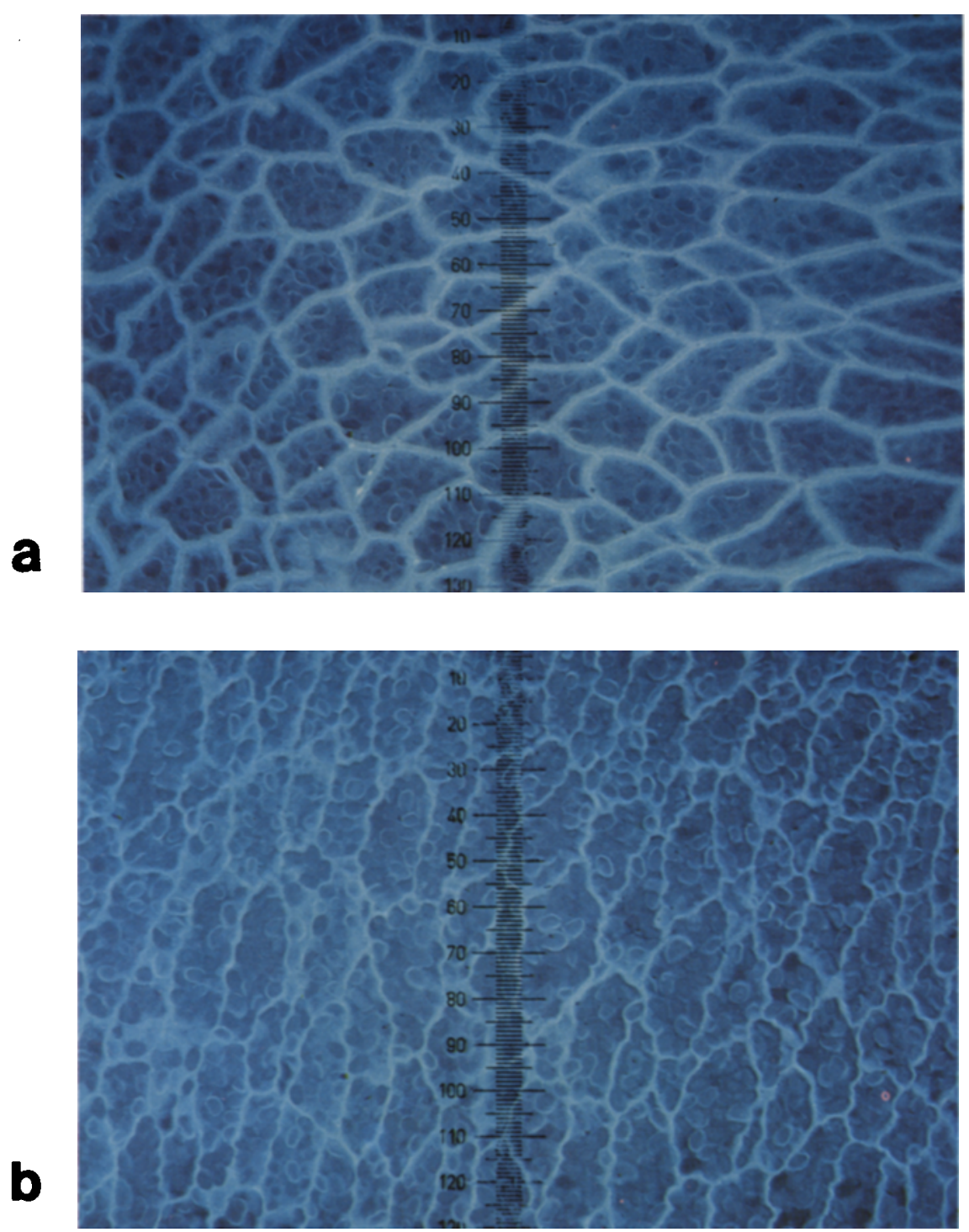

Figure 5: Thin-sections ( $7 \mu \mathrm{m}$ ) of (a) Minerva and (b) M-737 stained with Calcofluor and Fast Green as seen in the fluorescence microscope. 1 graduation mark: 2.5 $\mu \mathrm{m}$. Analogous preparations of M-699 and M-892 are indistingishable from Minerva, while that from $M$ 1460 is identical to M-737.

Figure 6: Thin-sections (7 $\mu \mathrm{m}$ ) of (a) Minerva and (b) M-737 stained with Calcofluor and Fast Green as seen in the fluorescence microscope. 1 graduation mark: 4 $\mu \mathrm{m} .(\rightarrow)$ Starch granule cutting into the endosperm cell wall.

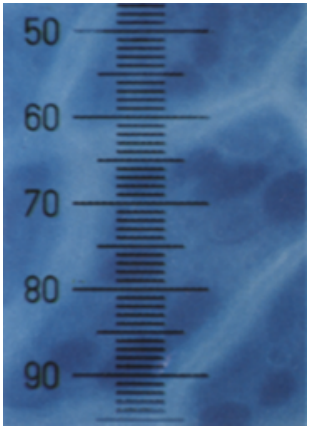

a

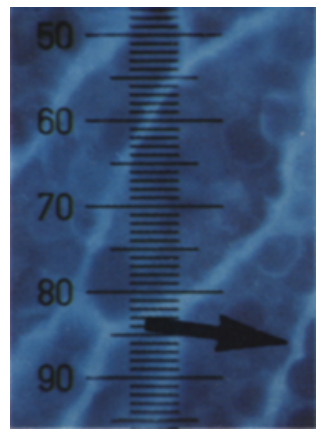

b 
1460 were highly modified compared to that of Minerva, M-699 and M-892 as seen from the low viscosity and high colour figures. In addition $\mathrm{M}$ 1460 and M-737 were dried down to a lower moisture content.

\subsection{Cell wall thickness and cell number}

To determine whether the decrease in $\beta$-glucan content was connected with any morphologically recognizable change in the seeds, thin sections of seeds were analysed for cell wall thickness and cell number (Figure 5). The cell walls of Minerva, M-699 and M-892 measure 6.0 to $6.5 \mu \mathrm{m}$, while those of M-737 and M-1460 were about half this thickness (Table IV). Thus the differences in cell wall thickness seen under the microscope clearly parallel differences in the $\beta$-glucan contents (Table I). While the cell walls of the Minerva, M-699 and M-892 are thick and straight, the more slender cell walls of M-737 and M-1460 are undulated. Although the cell numbers of the five genotypes are not significantly different, the mutants showed a greater diversity in cell size as deduced from the standard error figures (Table IV).

\section{DISCUSSION}

A low viscosity of acid extracts of barley flours has been shown to indicate low $\beta$-glucan content and good malting quality $(2,15,24)$, although the overall correlation between viscosity of acid extract and total $\beta$-glucan is poor $(2,29)$. In the present study, however, a quick screening method based on barley extract viscosity ( 2 ) was used successfully in the search for low $\beta$-glucan mutants of the high $\beta$-glucan barley variety, Minerva.

Four lines with acid flour extracts of extremely low viscosity were isolated using this method. Two (M-737, M-1460) were low in total $\beta$-glucan content, while the others (M-699, M-892) contained relatively high levels of total $\beta$-glucan, confirming the earlier observations that the ratio of soluble to total $\beta$-glucan in barley varieties can vary significantly $(2,3,29)$. The reason for this is uncertain, but it is apparent that little or no $\beta$ glucan soluble at $\mathrm{pH} 1.5$ is synthesised in the four mutant lines.

As the $\beta$-glucans account for $75 \%$ of the dry matter content of endosperm cell walls (12) physical changes in the cell walls of the low $\beta$ glucan mutants might be expected. Such differences were suggested by FINCHER (12), who stated that the thickness of the endosperm cell walls was likely to vary depending on growth conditions and variety, although he was not able to detect any differences in the cell wall thickness between two varieties of contrasting malting ability (Maris Otter and Julia) by scanning electron microscopy. Indeed, very few workers have looked at cell wall thickness in their search for endosperm characteristics which might explain different malting behaviour. PALMER and HARVEY (25) examined endosperm structure of the good malting variety Proctor and the poor malting variety Julia using scanning electron microscopy. They found that the endosperm of Julia appeared to be more rigid and compact than the equivalent endosperm of Proctor, but they did not report any differences in cell wall thickness. Similary Gram (14) could detect no differences between cell walls of varieties of varying malting quality (Minerva, Nordal and Klages) by freezefracture techniques. The reason that differences in cell wall thickness have not been observed might be that i) the differences have been too small, ii) different parts of the endosperm have been examined, ii) insufficient (or non-representative) cell wall sections have been measured, iv) there was, indeed, no difference in the cell wall thickness.

In contrast to these studies BorsSENNET and SCRiBan (9) using Calcofluor staining, light microscopy and scanning electron microscopy observed that the slow malting winter barley Sonja had markedly thicker cell walls than the fast malting spring barley Menuet. The present communication represents the second example of such a relationship between malting behaviour and cell wall thickness which in turn, may be related to the $\beta$-glucan content of the barley grains.

The mutant M-737 displays all the characteristics of a good malting barley as judged by the barley and malt analyses, the rapid rate of endosperm modification, the low $\beta$-glucan content and the mealy endosperm. The latter has traditonally been associated with good malting quality, and most good malting barleys have a high percentage of mealy kernels. The reason for 
the mealy and steely appearance of grains is uncertain, but PALMER and HARVEY (25) have found that steely kernels have higher protein content than corresponding mealy ones. In addition, the mealy grains have lower sedimentation values and marginally less $\beta$-glucan than steely grains. Results of the present study are consistent with a relationship between mealiness and $\beta$-glucan content, but not with a relation to protein content since both Minerva and M-737 have the same protein figures.

Morphological examination revealed that the endosperm cell walls of mutant M-737 were not only thinner than those of the parent variety, but also exhibited a marked crinkly or undulating appearance (Figure 5). It has been suggested that adpression of starch granules causes distortion of the inner cell wall surface during endosperm development (12) and it is possible that the crinkly appearance of the thin M-737 walls results from their deformation during starch deposition (Figure 6). Alternatively, the crinkly appearance may result from deformation of the thin cell walls during section preparation.

Comparing the malting of Minerva and $\mathrm{M}$ 737, which contain similar amounts of $\beta$ glucanase, the effect of cell wall thickness on the speed of modification is demonstrated. The low $\beta$-glucan, thin-walled mutant malted much more quickly than the high $\beta$-glucan parent variety, supporting the views of MACLEOD (20), that the biggest obstacle to the conversion of barley to satisfactory malt is the network of endosperm cell walls. This view is based on the suggestion that the $\beta$-glucan-rich cell walls must be broken down before any hydrolysis of starch and protein takes place and has been recently demonstrated by Gram (14). Furthermore, a comparison of the malting of M-737 and M-1460 shows the importance of high $\beta$-glucanase activity for the rate of modification as pointed out by WAINWRIGHT (32). The very rapid malting of M-1460 compared to Minerva can thus be explained as a combination of its thinner cell walls and higher enzyme activity.

The M-1460 mutant, however, is not only a low $\beta$-glucan mutant but also a high lysine mutant of the Risø 1508 type and is characterised by lack of hordeins, enlarged embryo, shriveled endosperm etc. which might influence the rate of modification. Risø 1508 has earlier been shown to be low in both barley extract viscosity and total $\beta$-glucan content ( 2 ). It is therefore likely that the low $\beta$-glucan content of $\mathrm{M}$ 1460 is genetically connected with the high lysine phenotype, in contrast to M-737, which is a low $\beta$-glucan mutant lacking such pleiotropic effects.

The mutant M-737 therefore appears to be a genuine low $\beta$-glucan line which could be useful in studies on the factors which affect $\beta$-glucan synthesis in the developing endosperm. Furthermore, mutant M-737 might be introduced into breeding programmes, since relatively low $\beta$ glucan content is an important selection criterion in the production of new barley varieties (30, 32).

\section{ACKNOWLEDGEMENTS}

I want to thank BARBro JENDE-STRID for the sodium azide treatment, Carlsberg Plant Breeding and Crop Research Division (D.S.I.R.), Lincoln, New Zealand for growing the plants, Lisbeth Jensen, Maj-Britt Nielsen, Jane TinNING and METTE Høנ for technical assistance, and Drs. P. von Wettstein-Knowles, L. MunCK and G.B. Fincher for critical review of the manuscript. I am thankful to Dr. LARS MUNCK who introduced me to the $\beta$-glucan problems and guided my work in this field.

\section{REFERENCES}

1. AACC, Approved Methods/American Association of Cereal Chemists. Rev. and repr. ed., St. Paul, Minneapolis, AACC (1976)

2. Aastrup, S.: The relationship between the viscosity of an acid flour extract of barley and its $\beta$-glucan content. Carlsberg Res. Commun. 44, 289-304 (1979)

3. Aastrup, S.: The effect of rain on $\beta$-glucan content in barley grains. Carlsberg Res. Commun. 44, 381-393 (1979)

4. Aastrup, S. \& K. Erdal: Quantitative determination of endosperm modification and its relationship to the content of $1,3: 1,4-\beta$-glucans during malting of barley. Carlsberg Res. Commun. 45, 369-379 (1980)

5. Aastrup, S. \& L. Munck: Genetic and plant breeding studies of malting barley using new analyses for 1,3:1,4- $\beta$-glucan and cell wall modification during malting. 4th Int. Barley Genetics Symp., Edinburgh 1981, 186-195 (1982) 
6. Analytica-EBC, Analysis Committee of European Brewery Convention, T.-M. Enari ed., Schweizer-Brauerei-Rundschau. 3rd ed., Zürich, 87 pp (1975)

7. Anderson, M.A., J.A. COOK \& B.A. Stone: Enzymatic determination of 1,3:1,4- $\beta$-glucans in barley grains and other cereals. J. Inst. Brew. 84, 233-239 (1978)

8. BAMForTh, C.W.: Barley $\beta$-glucans, their role in malting and brewing. Brewers Digest, June, 22-27, 35 (1982)

9. BoIsSONNET, E. \& R. SChriban: Observations on the evolution of the subaleurone and albumen in brewing barley during malting. Brauwissenschaft 35 (8), 189-198 (1982)

10. BuRnetr, G.S.: Studies of viscosity as the probable factor involved in the improvement of certain barleys for chickens by enzyme supplementation. British Poultry Science 7, 55-75 (1966)

11. ColEs, G.D.: Accumulation of free sugars and glucosan in developing barley kernels. Carlsberg Res. Commun. 44, 439-453 (1979)

12. FinCHER, G.B.: Morphology and chemical composition of barley endosperm cell walls. $J$. Inst. Brew. 81, 116-122 (1975)

13. GibBons, G.C.: On the location and transport of $\alpha$-amylase during germination and early seedling growth of Hordeum vulgare. Carlsberg Res. Commun. 44, 353-366 (1979)

14. GRAM, N.H.: The ultrastructure of germinating barley seeds. II. Breakdown of starch granules and cell walls of the endosperm in three barley varieties. Carlsberg Res. Commun. 47, 163-185 (1982)

15. Greenderg, D.C. \& E.T. Whitmore: A rapid method for estimating the viscosity of barley extracts. J. Inst. Brew. 80, 31-33 (1974)

16. Hesselman, K., K. Elwinger, M. Nilsson \& S. THOMKE: The effect of $\beta$-glucanase supplementation, stage of ripeness and storage treatment of barley in diets fed to broiler chickens. Poultry Sci. 60, 2664-2671 (1981)

17. HesselmaN, K. \& S. THOMKE: Influence of some factors on development of viscosity in the water-extract of barley. Swedish J. Agric. Res. 12, 17-22 (1982)

18. IngVersen, J., B. KoIf \& H. Doll: Induced seed protein mutant of barley. Experientia 29, 1151-1152 (1973)

19. Jende-STRID, B.: Mutation frequencies ob- tained after sodium azide treatment in different barley varieties. Barley Genetics Newsletter 8, 55-57 (1978)

20. MACLeOD, A.M.: Malting: Quo Vadis? MBAA Tech. Quart. 15, 65-75 (1978)

21. MacGregor, A.W. \& R.R. Matsuo: Starch degradation in endosperms of barley and wheat kernels during initial stages of germination. Cereal Chem. 59, 210-216 (1982)

22. Munck, L., G. Gibbons \& S. Aastrup: Chemical and structural changes during malting. Eu. Brew. Con. Proc. Congr., Copenhagen, 11-29 (1981)

23. Olsen, O.-A. \& T. KrekLiNG: Grain development in normal and high lysine barley. Hereditas 93, 147-160(1980)

24. PAlmer, G.H.: The morphology and physiology of malting barleys. Proc. Int. Conf. Cereals for Food and Beverages (ed. G.E. Inglett and L. Munck), Acad. Press, New York, 301-330 (1980)

25. Palmer, G.H. \& A.E. Harvey: The influence of endosperm structure on the behaviour of barleys in the sedimentation test. J. Inst. Brew. 83, 295-299 (1977)

26. Preece, I.A. \& K.G. MacKenzie: Non-starchy polysaccharides of cereal gums. I. Fractionation of the barley gums. J. Inst. Brew. 58, 353362 (1952)

27. RHODES, A.P: A comparison of two rapid screening methods for selecting high lysine barleys. J. Food Sci. 26, 1703-1710 (1961)

28. Sandegren, E. \& L. Enebo: Cell wall decomposing of barley and malt. I. Determination and stability investigations. J. Inst. Brew. 58, 198-203 (1952)

29. Smith, D.B., A.G. Morgan \& S. Aastrup: Variation in the composition of acid extracts from barley of contrasting malting quality. $J$. Inst. Brew. 86, 277-283 (1980)

30. Sparrow, D.H.B. \& W.O.S. Meredith: Malt cytolytic activity of barley of diverse origins and its relation to maltability. J. Inst. Brew. 75, 237-242 (1969)

31. Theander, O. \& P. Aman: Studies on dietary fibre. A method for the analysis and chemical characterisation of total fibre. J. Sci. Food Agric. 33, 340-344 (1982)

32. WAINWRIGHT, T: The selection of barley varieties for malting and brewing. The Brewer, Sept. 314-317 (1979) 